\title{
The Effect of Flashcards on Students in Writing Vocabulary at Seventh Grade of MTs Al Ulum
}

\author{
Nurhalimah $^{1}$, Sumarsih ${ }^{2}$, Rahmad Husein ${ }^{3}$ \\ \{nhalimahhalimah227@gmail.com ${ }^{1}$, prof.sumarsih@gmail.com ${ }^{2}$, rhnapitupulu@yahoo.com ${ }^{3}$ \} \\ Doctoral Programs in English Applied Linguistics in English Applied Linguistic Study Program, \\ Universitas Negeri Medan, Medan, Indonesia ${ }^{1}$, Postgraduate in English Applied Linguistic Study \\ Program, Universitas Negeri Medan, Medan, Indonesia ${ }^{2,3}$
}

\begin{abstract}
This study was examined students writing vocabulary by using flashcards; the method is a qualitative and quantitative method, where the data collected and analyzed through statistical analysis. The type of research was experimental research. And the students will give a pretest to find their vocabulary before being given treatment. After that, we're given a post-test toward their language. In the seventh grade of MTs Al Ulum Medan, the populations of this research were students. The large number was limited that 20 students were chosen as the sample. This method aims to train the right brain's ability to recall images and words so that the students' vocabulary and writing skills can be taught and improved. And the result showed that the treatment of the students in writing vocabulary is an increase. It can be seen from the resulting test after treatment. It means flashcards are suitable for improving students' writing skills, especially for seventh-grade students who beginners level in English.
\end{abstract}

Keywords: Writing, Vocabulary, and Flashcard.

\section{Introduction}

The fundamental function of language is an instrument of communication. English is used by millions of people all over the world. In Indonesia, English is considered a foreign language taught to be elementary school up to university. In the education aspect, the students hope to speak and write in English to technology development. Teaching English in the junior high school (SMP) curriculum covers four skills: reading, listening, speaking, and writing. Writing is part of language skills and an enjoyable practice since the definition can be completely articulated in either as a document of an event in history or as a statistical analysis, a paper document by anyone. In communicating a language, writing has significance as a means of communication. It is possible to convey meaning by hand because it is a tool in a written organizational system. Byrne [1] He suggested that we use graphic symbols when we write: letters or letter combinations that refer to the sounds we make when we write. In fact, this idea will explain the writer's opinions, emotions, interests, and feelings, and one is so used to writing would be able to discover his distinctive personality inside himself and convey it.

While To each of us, writing is important, particularly for students, it is a complicated discussion. The interpretation is that, in particular, writing is a combination of our thoughts, grammar, and vocabulary. It is the responsibility of the teacher to encourage learners to react to specific grammatical errors in their own written discourse in their passive grammatical 
knowledge and develop lexical accuracy techniques and expand the academic vocabulary. Vocabulary is one of the essential elements of language that can be produced by the learner. Having a lot of speech will allow the students to make the phrases and ultimately lead them to develop contacts. It is, therefore, quite important to learn a great deal of English vocabulary to acquire communication skills. Sometimes, language is more important than grammar. Learning that they cannot interact effectively is frustrating for intermediate students because they do not know all of the terms they need [2].

A selection of words requires vocabulary. Words are not only recognized as individual words but also as a group of meaningful words. To improve students' language skills in reading, listening, speaking, and writing, they need to have certain levels of vocabulary. David Nunan [3] stated, "The vocabulary learning has acquired its proper position as the critically important component of language learning." It is assumed that someone should have the stock of vocabulary to develop their English. The teachers may employ specific strategies to optimize classroom activities, such as using appropriate approaches concerning the students' characteristics to get bored quickly. It is essential to consider what kind of process can be used to make English for young students to become comfortable and exciting. To get the students' attention, it is necessary to create a class situation that can motivate the students to study.

One of the ways to create the class more interesting is through media. Meriam stated that "Flashcard is a card bearing words numbers of pictures that are briefly displayed (as by a teacher to a class) usually as a learning aid." Flashcards are widely used as a learning drill to aid memorization by way of spaced repetition. Flashcards are an exciting media that it will inspire students. Flashcards can be used to explain the meaning and construction of the language, to engage students in the subject, or as a basis for all activities. Concerning that, there are many ways of using writing vocabulary. So, from the explanation, the writer wants to find the effects of using flashcards on the students' writing vocabulary.

\section{Materials}

\subsection{Writing}

Communication is crucial in this modern age, and so many of us need to connect with each other, even though we are far distance. And, of course, it is generally recognized that the medium of writing has successfully become a language of international communication. One of the often required communication skills in writing. Speaking and listening, however, take up a significant proportion of time human beings spend in conversation, writing, which is a more complex method for most people to demand than talking. When speaking and listening start early in the life of the kid.

Writing ability can be described as the ability to express ideas through written symbols by arranging the arguments to convey the following on the basis of the rules of the Language system to allow others to understand the written message. These abilities include: (1) the learn how to write a word; (2) the ways of organizing words into sentences; (3) the writing a phrase; (4) the ability to construct a paragraph; and (5) the knowledge to implement a long text.
a. David Nunan[4] claimed that it involved good writing:
b. Mastering the letter shape mechanic,
c. Mastering and obeying spelling, vocabulary, and punctuation conventions,
d. Using the grammatical system to express the expected significance of one, 
e. Organizing material at the paragraph level and complete text to represent the structure of the given/ new information and topic/comment,

f. Polishing a review of one's original attempts.

\subsection{Vocabulary}

According to Penny [5], "Vocabulary can be defined, roughly, as the words we teach in the foreign language." A new vocabulary item, however, can be more than a single word: handphone and mother-in-law, for example, consisting of two or three words but communicating a conceptual model.

\subsubsection{Principles for Teaching Vocabulary}

Learners see vocabulary as being an essential part of language learning, and one of the difficulties in planning the vocabulary component of the course is making sure that it does not other whelm other critical factors in the system. The best way to avoid this is for the teacher and course designer to have a set of guiding principles that can be applied in various teaching and learning situations by David Nunan. They are:

a. Focused on the most useful vocabulary first.

The most useful vocabulary that every English language learner needs, whether they use the language for listening, speaking, reading, or writing, or using the language in formal and informal situations, is the most frequent 1000 words families of English. This vocabulary is so useful that it covers around 75 percent of the running words in academic texts and newspapers, over 80 percent of the running words in novels, and about 85 percent of the running world in conversation. It involves most of the 176 families of function words (a story like a, since, could) and words such as hold, kind, knowledgeable, lack, and ground. It is possible to say and write a lot using only the first 1000 words of English.

b. Focus on the vocabulary in the most appropriate method

There are four main learning strategies for vocabulary: using word elements, guessing meaning, Term cards are being used, and dictionaries will be used. One of the appropriate processes for children is using word cards; they memorize new words.

c. Give attention to the high-frequency words; the four strands of a course's high-frequency vocabulary needs to occur in all for strands of course. It should get deliberate attention through teaching and study and be met and used in communication messages in listening, speaking, reading, and writing. High-frequency vocabulary for receptive and productive use should also be accessible fluently.

d. Encourage learners to reflect and take responsibility for learning.

Behind choice and learning, there is a significant philosophy, And that is, students need to recognize that they'll have to be responsive for their training. Take this task includes:

1. Knowledge of where to practice and the selection of learning vocabulary tools.

2. Ability in choosing the best option.

3. The ability to monitor and evaluate progress with those options.

In accordance with the approach and the media they use, this idea must be grasped by students. 


\subsubsection{Element to be taught in Vocabulary}

In vocabulary instruction, Penny needs to be educated a lot of them; they are:

a. Form: pronunciation and word order

The learner must understand what a word (its pronunciation) sounds like and what it looks like (its pronunciation) and what it looks like (it is the spelling). We need to make sure that all these things are addressed and learned correctly.

b. Grammar

For example, when teaching a new verb, we might also its part form if this is irregular (think, though), and we might note if it is transitive. Similarly, when teaching a noun, we may wish to present its plural form, if irregular (mouse, mice), or draw the learner's attention because It does not have a plurality in anyway, (advice, Knowledge information).

c. Collocation

Another aspect that makes one specific arrangement appear 'right' or 'wrong' in a particular context is the pronouns typical of specific items. So this is another piece of knowledge which might be necessary to teach about such a specific element.

d. The significance component: referent, subtext, adequacy

The interpretation of the word in the actual world, its referent, is essentially what something applies to; that was also the sort of description provided in a vocabulary. A dog indicates some kind animal, for course.

"Connotation is the associations, or positive or negative feelings it evokes, which may or may not be indicated in a dictionary definition." The word dog, for example, has a positive connotation of friendship and loyalty, as known by most British people. In comparison, As the amount of respondents in Arab countries recognize, the equivalent in Arabic has positive correlations with dirt and inferiority.

How its relevance of one element applies to the relevance of the others also might be important in teaching. There are distinguished connections such as this one: most of the other primary places are already here.

1. Synonymy Points which represent the same and the mostly the same; bright, imaginative, intelligent, for instance, It can serve as a synonym for knowledgeable.

2. Antonyms

Things which indicate the opposite; a weak antonym is large.

3. Hyponyms Items that serve as particular examples of a general definition are the animal hyponyms, dog, lion, mouse.

4. Co-hyponymy

The 'same sort of thing' or examples are other items; Red, blue, green, and brown are perfect.

5. Super ordinates

Common principles that encompass particular things; the animal is the dog's superior, the lion's mouse.

6. Translation

Phrases in the mother tongue of the learners that are (more or less) similar in understanding to the knowledge given.

7. Formation of Terms 
In teaching vocabulary, the teacher also needs to explain the process of prefixes and suffixes.

\subsection{Flashcards}

Usman [6] states, 'Media is an intermediary used to relay messages and to encourage the public (students)' thinking, feeling and success in facilitating the learning process.' Media means intermediary or presentation. Media are all modes that are designed to channel information transmission, according to the Association for Education and Communication Technology (AECT) [7].

The media will improve the learning process of students, and the subject matter submitted to the teacher would be quicker and easier to understand. Adding visuals to a lesson improves retention from 14 to 38 percent, according to Silberman [8]. When vocabulary is taught using visual aids, studies have also shown an increase of up to 200 percent." One of the visual aids used in memorizing new words is introduced by Glenn Doman, a brain surgeon from Philadelphia, Pennsylvania. The flashcards' pictures are grouped among others be: a series of animals, fruits, and clothing. Children play a color form of numbers and so forth, Flashcards; it is appropriately read, just in time 1 second for each card by Arseto [9]."

Flashcards that have pictures and words would be one exciting medium in teaching vocabulary. So, a learner is busy with learning and memorizing activities that sometimes make the learners get boring. Still, it can also make the students comfortable in playing but was able to learn new vocabulary.

There are strategies for using flashcards in writing vocabulary; they are:

1. Practice Important Question: Application 1: Materials; flashcards, sheets of blank paper

Show flashcard questions and ask participants to speak with a response or show responses and ask them questions. They can also ask the students to write down the question or answer. Setting up question flashcards around the room and asking students to go to each one and write down an answer to the question is another alternative.

2. Write Stories or Sentences Application 2: Materials: flashcards, blank paper sheets Send student groups a set of different flashcards of words or pictures. Ask them to develop a creative way to use them all in a sentence, write questions, make true or false statements, or write a novel using the vocabulary of the cards. Make their sentences, questions, or plot clarified by the learners. Try to have the students write the logical or illogical term the flashcard uses for the longest possible time. Distinguish between supporting more accomplished students to take on the story-writing challenge while encouraging others to write statements or questions.

3. Application 3: Define an Image: Materials: flashcards, blank paper sheets Send students a calendar image or another image that has a scene. Ask them to write a story that goes with it, ask questions about the idea, give the image a title, or write a mix of reasonable and nonsensical statements about it to clarify the image.

4. Application 4: Word Brainstorm with Alphabet Letters: Materials: alphabet flashcard, blank sheet of paper

They are using alphabet flashcards to get people or groups to brainstorm a list of all the terms they know that begin with the letter. Have them do this by going through a few stations with various letters or receiving three to four random letters. See how long they can form a sentence, where all the words start with the same letter, as an additional challenge. 
5. Application 5: Combines of Unrelated Concepts: Materials: flashcards, blank sheet pages

Focus on providing students in group pairs with a few unrelated flashcards and ask them to write words, questions, or stories that create a connection between them. Ask learners also to have an example.

6. Application 6: Seeking Fairy Tales Inspiration: Materials: flashcards, sheets of blank paper

To inspire fairy tales that children can write, use decks of cards such as Old Maid, Go Fish, and other matching games as a graphic source.

7. Application 7: Games for Play: Material: Flashcards

To play around the world, use flashcards, Five, Charades, Pictionary, Inside-Outside Circle activities, and question-answer game. But in this research, the writer used flashcards in a question-answer game as application seven above. "The age of students is a major factor in teacher's decisions about how, what to teach, and what strategy that wants to use in the learning." We might expect students of primary age to acquire new vocabularies through play, using visual media, and fun activities for people with different needs, competencies, and cognitive skills. Especially for students in the SMP grade, optical media (such as flashcards) in a game is one of the best teaching strategies to motivate them in learning vocabulary.

\section{Method}

\subsection{Concept of Analyses}

The method of analysis included in this analysis was the qualitative method, where the data was collected and analyzed through statistical analysis. The type of research was experimental of research. In this research, the writer wanted to examine the influence of using flashcards on the comprehension of students' written vocabulary. In this research, the students were given a pretest to see their vocabulary before being given treatment. After treatment, a post-test to assess the validity of the experiment on their language has been provided to the students.

\subsection{The Analysis and Populace}

The target population comprised seventh-grade learners. of MTs Al ulum Medan. This class is made up of 20 students. The seventh grade of the MTs Alum Medan consists of 12 females and 8 males. According to Arikunto [10], "Population is a set or collection of all elements processing one or more attributes of interest." The population of this research was students in the seventh grade of MTs S Al ulum Medan. For the efficiency and practicality of this research, the large number of the sample was limited. Arikunto said that "if the population is similar to one hundred students, we can take them all as the sample." In this research, 20 students were chosen as the sample.

\subsection{Instrumentation}


In this research, the test was used as an instrument. The students were given a test to know and get the data about students writing vocabulary that consists of 40 questions. The test was multiple-choice tests with four alternatives $\mathrm{a}, \mathrm{b}, \mathrm{c}, \mathrm{d}$. The students were given time 45 minutes. If the students can answer all the questions correctly, the score was 10. It means that the correct answer will be given a score of 0,25 , while the wrong answer will be provided.

Table 1. Indicator of the Test

\begin{tabular}{lcccc}
\hline \multicolumn{1}{c}{ Indicator } & \multicolumn{4}{c}{ Items No. Items Score Total Score } \\
\hline Parts of School & 6 & $1-7$ & 2,5 & 15,0 \\
Parts of House & 7 & $7-13$ & 2,5 & 17,5 \\
Parts of Body & 7 & $14-20$ & 2,5 & 17,5 \\
Classroom Object & 7 & $21-27$ & 2,5 & 17,5 \\
Family & 6 & $28-33$ & 2,5 & 15,0 \\
Jobs and the Responsibilities & 7 & $34-40$ & 2,5 & 17,5 \\
Total Score & & & & 100,00 \\
\hline
\end{tabular}

\subsection{Data collection techniques}

The writer collected it by giving a test in order to obtain the data. The test is some of the questions used to measure skills, knowledge, and intelligence. The trial divided into two kinds: they are:

a. Pretest

Before the treatment, a pretest would be given to the students. It would be aimed to measure the students' skill in writing vocabulary before applying for the test.

b. Post-test

After conducting the treatment, a post-test was given to the students. Posttest is the same as Pretest. The post-tests administrating was mean to find out the differences in score before and after the treatment.

\subsection{The Procedure of the Research}

In conducting the research, the writer took the following step:

The study was done by observing the seventh grade of MTs Al Ulum Medan as the research object, then set the research and prepared test.

a. The writer gave Pretest to the students to know their achievement in writing vocabulary.

b. You are explaining vocabulary by using flashcards to the students.

c. The writers gave them a post-test after giving the treatment to assess their writing after receiving the treatment.

d. From the analysis of the data, the writer takes the conclusion.

\subsection{Data Processing Methodology}


In this research, qualitative data were also used. The qualitative information from the observation and the quantitative data from the written vocabulary examination of the students. The following formula was applied Identify the student's average points.

$$
\mathrm{X}^{2}=\mathrm{xN}
$$

$\begin{aligned} \text { Where: } \mathrm{X}^{-} & =\text {The total points for the learners } \\ \mathrm{X} & =\text { Complete Having scored } \\ \mathrm{N} & =\text { The cumulative amount of students in the program course. }\end{aligned}$

\section{Result and Discussion}

\subsection{Data}

To evaluate the effect of using flashcards on students' writing vocabulary, the writer has calculated the data by Pretest and post-test. Next, the writer described the data as follow:

\subsubsection{Data Pretest}

Table 2. Students' score in Pretest

\begin{tabular}{ccccc}
\hline No_ Students' Initial Name Correct & Score Category \\
\hline 1 & SG & 22 & 4.40 & Enough \\
2 & ST & 25 & 5.0 & Enough \\
3 & VA & 10 & 2.0 & Low \\
4 & RDU & 18 & 3.6 & Low \\
5 & HZ & 24 & 4.8 & Enough \\
6 & DM & 11 & 2.2 & Low \\
7 & ZAF & 12 & 2.4 & Low \\
8 & AL & 20 & 4.0 & Enough \\
9 & SR & 15 & 3.0 & Low \\
10 & ESY & 14 & 2.8 & Low \\
11 & DL & 20 & 2.4 & Low \\
12 & NR & 18 & 3.6 & Low \\
13 & DA & 16 & 3.2 & Low \\
14 & FR & 15 & 3.0 & Low \\
15 & DW & 7 & 1.4 & Enough \\
16 & SK & 15 & 3.0 & Low \\
17 & LT & 16 & 3.2 & Low \\
18 & RR & 12 & 2.4 & Low \\
19 & AG & 12 & 2.4 & Low \\
20 & WY & 12 & 2.4 & Low \\
\hline
\end{tabular}

The performance value of learners in Pretest It is shown in the section following table:

Table 3. The percentage of Average of both the students during Pretest 


\begin{tabular}{ccrccc}
\hline No & X & Xi & Fi Fi, xi & $\%$ \\
& & & & \\
\hline 1 & $4.5-5.44 .95$ & 2 & 9.9 & $10 \%$ \\
2 & $3.5-4.43 .95$ & 5 & 19.75 & $25 \%$ \\
3 & $2.5-3.42 .95$ & 5 & 14.75 & $25 \%$ \\
4 & $1.5-2.41 .95$ & 7 & 13.65 & $35 \%$ \\
5 & $0-1.4$ & 1.4 & 1 & 1.4 & $5 \%$ \\
\hline
\end{tabular}

Table 4. The class proportion in writing vocabulary in Pretest

\begin{tabular}{ccc}
\hline \multicolumn{2}{l}{ Category } & Frequency \\
\hline Very high & - & $\%$ \\
High & - & $\%$ \\
Enough & 4 & $20 \%$ \\
Low & 15 & $75 \%$ \\
Very low & 1 & $5 \%$ \\
\hline
\end{tabular}

They range from very high, high, appropriate, low, and very low, respectively. It has been shown that there is a student who is sufficiently classified (20\%) and low sort (75\%), the students who have deficient variety one student (5\%), so in Pretest the students' score in writing vocabulary have a common type.

\subsubsection{Data Post-Test}

Table 5. Students' Post-Test Value

\begin{tabular}{ccccc}
\hline No_ & Students' Initial Name & Correct & Score & Category \\
\hline 1 & SG & 36 & 7.2 & High \\
2 & ST & 37 & 7.4 & High \\
3 & VA & 30 & 6.0 & Enough \\
4 & RDU & 31 & 6.2 & High \\
5 & HZ & 36 & 7.2 & High \\
6 & DM & 28 & 5.6 & Enough \\
7 & ZAF & 30 & 6.0 & Enough \\
8 & AL & 33 & 6.6 & High \\
9 & SR & 28 & 5.6 & Enough \\
10 & ESY & 26 & 5.2 & Enough \\
11 & DL & 35 & 7.0 & High \\
12 & NR & 33 & 6.6 & High \\
13 & DA & 28 & 5.6 & Enough \\
14 & FR & 30 & 6.0 & Enough \\
15 & DW & 25 & 5.0 & Enough \\
16 & SK & 29 & 5.8 & Enough \\
17 & LT & 28 & 5.6 & Enough \\
18 & RR & 30 & 6.0 & Enough \\
19 & AG & 29 & 5.8 & Enough \\
20 & WY & 31 & 6.2 & High \\
\hline
\end{tabular}

The number of post-test academic performance can be seen from the present study: 
Table 6. Amount of Pretest Class Rating

\begin{tabular}{cccccc}
\hline No & $\mathrm{X}$ & $\mathrm{Xi}$ & $\mathrm{Fi}$ & $\mathrm{Fi}, \mathrm{xi}$ & $\%$ \\
\hline 1 & $6.5-7.4$ & 6.95 & 6 & 41.7 & $30 \%$ \\
2 & $5.5-6.4$ & 5.95 & 12 & 71.4 & $60 \%$ \\
3 & $4.5-5.4$ & 4.95 & 2 & 9.9 & $10 \%$ \\
4 & $3.4-4.4$ & 3.95 & - & - & $\%$ \\
5 & $2.5-3.4$ & 2.95 & - & - & $\%$ \\
\hline
\end{tabular}

Table 7. The percentage of Students in writing vocabulary in post-Test

Category Frequency Percentage

\begin{tabular}{ccc}
\hline Very high & - & $\%$ \\
High & 8 & $40 \%$ \\
Enough & 12 & $60 \%$ \\
Low & - & $\%$ \\
Very low & - & $\%$ \\
\hline
\end{tabular}

The table above ranges from very high, high, enough, low, and very low. It can be seen that is a student comes into a very high category (40\%), the students who enough type are 12 students $(60 \%)$, there is no student in the low class and deficient category.

According to Riduwan, the students; the identification of the result should always be described in the result section:

Table 8. The Average Identification of Candidates

\begin{tabular}{cc}
\hline Score & Category \\
\hline $81-100$ & Very high \\
$61-80$ & High \\
$41-60$ & Enough \\
$21-40$ & Low \\
$0-20$ & Very low \\
\hline
\end{tabular}

(Resource: Riduwan, Belajar Mudah Penelitian Untuk Guru, Karyawan dan Peneliti Paula)

In this research, it was found that the students' writing vocabulary was weak. They can't express their idea in writing because of a lack of vocabulary. The writer gave them Pretest before treatment; most of the students cannot answer the questions. After doing the observation, the writer found the problem. A strategy used in teaching vocabulary is boring, So the motivation of students to learn English, especially in the language, is poor. The writer attempted to offer the treatment by using flashcards from the issue. Flashcards are the picture cards that have the words introduced by Glenn Doman, a brain surgeon from Philadelphia, Pennsylvania. The pictures on flashcards categorized, among others, the series of parts of the body, parts of the school, parts of the house, classroom objects, Family words, and kinds of occupations. The cards are played in a way shown to the children and read quickly, in just 1 second for each card. This method aims to train the right brain o recall images and words so that students' vocabulary and writing skills can be taught and improved. 
The result of the treatment on students in writing vocabulary is increasing. After treatment, From the post-test outcomes, that can be seen. It means flashcards are suitable for improving students' writing language skills, especially for seventh-grade students who beginners level in English subject.

\section{Conclusion}

That one was discovered that flashcards could get the reading instruction vocabulary since collecting the results. It can be seen from the score of the student before and after treatment. The students' total score in writing speech in the present was 59.45; it is lower than the students' score in writing vocabulary Either through the post-test. The students' total points in the posttest was 122.6. So, the research results are flashcards have a significant effect on students ' writing vocabulary and could help the students increase their language.

Acknowledgments. The authors thank the Universitas Department of Postgraduate in English Applied Linguistic Study Program, State University of Medan/Unimed, to encourage and facilitate the authors to complete this research.

\section{References}

[1] Byrne D 1979 Teaching Writing Skill (Singapore: Longman) p 1

[2] Davies PM and Eric P 2000 Success in English Teaching (Oxford University Press: Oxford Handbooks for Language Teachers) p 59

[3] Nunan D 1999 Second Language Teaching \& Learning: Newbury House Teacher Development (Boston: Heinle \& Heinle Pub) p113

[4] Nunan D 1989 Second Language Teaching \& Learning: Newbury House Teacher Development, (Boston: Heinle \& Heinle Pub) p 37

[5] Penny U 1998 A Course in Language Teaching: Practice and Theory (Cambridge: Cambridge University Press) p 90

[6] Usman B Teaching -- Instruction and Study (Jakarta: Ciputat Pers) 2002 p 11

[7] Sabri A 2005 Strategi Belajar Mengajar dan Micro Teaching (Jakarta: Quantum Teaching) p 2

[8] Silberman M 1996 Active Learning: 101 Strategies to Teach Any Subject Allyn and Bacon p 2

[9] Arseto J 2010 A Thesis: Pengaruh Penggunaan Flashcard Terhadap Penguasaan Vocabulary Pada Siswa Sekolah Dasar Kelas V di SD Negeri Muarareja 01 dan 02 Tahun Pelajaran 2008/2009 Universitas Pancasakti Tegal p 30

[10] Book: Arikunto S 1996 Prosedur penulisan: Suatu Pendekatan Praktik (Jakarta: Bina Aksara) p 20 